Tér és Társadalom 18. évf. 2004/3. 111-125. p.

Tér és Társadalom

XVIII. évf. 2004

3: $111-149$

\title{
VERSENYKÉPESSÉG
}

\section{A REGIONÁLIS INNOVÁCIÓS RENDSZER KÍNÁLATI OLDALA A KÖZÉP-DUNÁNTÚLON ${ }^{1}$}

\author{
(The Supply Side of the Regional Innovation Systems - \\ Case Study of Central Transdanubia) \\ GROSZ ANDRÁS - CSIZMADIA ZOLTÁN - \\ SZÉPVÖLGYI ÁKOS
}

Kulcsszavak:

innováció regionális innovaciós stratégia vállalkozásfejlesztés gazdaságfejlesztés terilletfejlesztés

A tanulmány célja, hogy megpróbálja feltámi és ósszegezni egy térség, jelen esetben a Közép-dunántúli régió valamennyi olyan szervezetét, intézményét és szereplöjêt, melyek a kinálati oldal aktoraként középés hosszú tâvon akár aktivan, akär passzivan hatást gyakorolhatnak a régió innovációs folyamataira. A kínálati oldalon megtalälható szereplök tevékenységének egy egységes, a hálózati együttmüködést és az eröteljes specializáción alapuló munkamegosztäst elótérbe helyezö koncepció részeként történö tudatos fejlesztése eredményeként lehet létrehozni azt a regionälis innovációs rendszert, amely hosszú távon képes hozzájárulni a régió jövöképének („A Közép-Dunántúl váljék az innováció régiójává”) megvalósitásához. A tanulmány a régió gazdasági szerkezetváltásának és kutatás-fejlesztési tevékenysêgének legfontosabb sajâtossägait követöen sorra veszi a leendö regionális innovációs rendszer lehetséges elemeit, így a felsöoktatási és kutatóintézeteket, az ipari parkokat és valamennyi olyan szervezetet (inkubátorhazak, vallalkozásfejlesztési szervezetek, klaszter kezdeményezések, kamarák stb.), amely szolgältatásaival hozzajarulhat a vállalkozások innovációs képességeinek javulásához.

\section{Bevezetés}

Az innováció az elmúlt évtizedekben bekövetkezett gazdasági-társadalmi változások eredményeképpen az egyik legfontosabb termelési tényezővé vált nemcsak a gazdasági fejlődés magterületéhez tartozó országokban, de hazánkban is. A vállalkozások - a felgyorsult technológiai fejlödés következtében - hosszú távon fenntartható versenyképességét csak a konkrét új piaci termékekben, szolgáltatásokban, termelési eljárásokban, szervezeti rendszerek bevezetésében, piaci magatartási formákban és értékesítési csatornákban megnyilvánuló és realizálódó folyamatos kutatás-fejlesztési tevékenység, innovációs aktivitás képes biztosítani.

Magyarországon a nemzeti és regionális innovációs rendszer legfontosabb elemeként egyértelmủen a magát az innovációt létrehozó, megvalósító gazdasági szervezetek jelölhetők meg. A vállalatok innovációs tevékenységét nagymértékben meghatározó legfrissebb kutatási eredményeknek a vállalatokhoz - különösen a kis- és közepes méretü vállalkozások számára - való eljuttatásában kiemelt szerepet kell, vagy kellene játszani a legkülönfélébb közvetítő, vagy hídképzö szervezeteknek. A 
vállalkozások innovációs tevékenységének vizsgálatával foglalkozó szakirodalom szerint a különbözö gazdasági szereplök innovációs, illetve kutatás-fejlesztési aktivitásában óriási különbségek tapasztalhatók, melyek alapja leginkább a vállalkozások mérete, de fontos tényező lehet a tevékenység, ágazati meghatározottság, tulajdonosi kör is (OMFB 1995; 1998; Mosoniné 1997; Grosz 2001; 2002; Goldperger 2002). A folyamatos innováció, a $\mathrm{K}+\mathrm{F}$ követelményének általában csak a megfelelő pénzügyi háttérrel rendelkező nagyobb vállalkozások képesek megfelelni. Ezért a nemzeti és regionális innovációs rendszer elemei között az innovációt megvalósító vállalkozások és az innovációk létrejöttében közreműködő, a kis- és középvállalkozások létrejöttét és fejlödését támogató széles körü intézményi és szervezeti körre is gondolni kell.

A vállalkozásokat, innovációs stratégiájuk és azok legfontosabb jellemzői alapján Buzás (2002) három jól elkülöníthető csoportba sorolja, melyek kapcsolódása, együttműködési lehetösége, valamint igénye a különböző transzfer és közvetítő szervezetekhez és azok szolgáltatásaihoz egymástól eltérő sajátosságokkal bír (1. táblázat). Míg az élenjárók elsősorban a kutatóintézetekkel és a felhasználókkal törekednek szoros partnerkapcsolatra, addig a korai követők föként a technológiai központokkal, az egyetemi kutatóintézetekkel alakítanak ki kooperatív kontaktusokat (Buzás 2002; Grosz 2002; MISZ 2002).

\section{TÁBLÁZAT}

A vállalkozások innovációs stratégiái és jellemzői (Innovation Strategies and Features of Enterprises)

\begin{tabular}{|c|c|c|c|}
\hline & $\begin{array}{c}\text { Élenjárók } \\
\text { (Get-Ahead) }\end{array}$ & $\begin{array}{c}\text { Korai követök } \\
\text { (Keep-Up) }\end{array}$ & $\begin{array}{l}\text { Kései alkalmazók } \\
\text { (Catch-Up) }\end{array}$ \\
\hline Stratégia & élre törő & lépéstartó & felzárkózó \\
\hline Képességek & $\begin{array}{l}\text { - meglévő technológiák } \\
\text { újszerú kombinációja } \\
\text { - a tudáshatárok } \\
\text { kiterjesztése }\end{array}$ & $\begin{array}{l}\text { - technológiamódosítás } \\
\text { - minőségjavítás } \\
\text { - költségcsökkentés } \\
\text { - kis léptékủ változtatás }\end{array}$ & $\begin{array}{l}\text { - problémamegoldó } \\
\text { innováció } \\
\text { - termelékenységnöve- } \\
\text { lés } \\
\text { - technológia másolás } \\
\text { - technológia adaptálás }\end{array}$ \\
\hline $\begin{array}{l}\text { Tudás- } \\
\text { ráfordítás }\end{array}$ & $\begin{array}{l}\text { tudományos kutatás, } \\
\text { technológia kidolgozás } \\
\text { és laboratóriumi model- } \\
\text { lek, a K+F és a piacosí- } \\
\text { tás cégen beliuli össze-- } \\
\text { kapcsolása }\end{array}$ & $\begin{array}{l}\text { mérnöki tervezés, kivi- } \\
\text { telezés, piacra dobás: a } \\
\text { tervezés és a gyártás } \\
\text { cégen belüli összehan- } \\
\text { golása }\end{array}$ & $\begin{array}{l}\text { mérnöki és menedzs- } \\
\text { ment adottságok: visz- } \\
\text { szajelzések a gyártási } \\
\text { folyamatokról, illetve a } \\
\text { termékvizsgálatról }\end{array}$ \\
\hline $\begin{array}{l}\text { Technológiai } \\
\text { célkitüzés }\end{array}$ & $\begin{array}{l}\text { vállalaton belüli kuta- } \\
\text { tás, technológiafejlesz- } \\
\text { tés, K+F hálózatok } \\
\text { kialakítása }\end{array}$ & $\begin{array}{l}\text { technológiai fejlesztés, } \\
\mathrm{K}+\mathrm{F} \text { hálózatok }\end{array}$ & $\begin{array}{l}\text { technológia-transzfer, } \\
\text { technológia elterjedése, } \\
\text { demonstrációs projek- } \\
\text { tek, oktatás, képzés }\end{array}$ \\
\hline $\begin{array}{l}\text { Partner- } \\
\text { kapcsolatok }\end{array}$ & $\begin{array}{l}\text { hosszabb távú } \mathrm{K}+\mathrm{F} \\
\text { együttmúködési projek- } \\
\text { tek kutatóintézetekkel, } \\
\text { felhasználókkal és } \\
\text { beszállítókkal }\end{array}$ & $\begin{array}{l}\text { egyetemek mérnöki } \\
\text { karai, tanácsadó cégek, } \\
\text { technológia intézetek, } \\
\text { felhasználók }\end{array}$ & $\begin{array}{l}\text { betanulási programok, } \\
\text { termelékenységi köz- } \\
\text { pontok, ügyfelek, be- } \\
\text { rendezések szállítói és } \\
\text { közvetítói }\end{array}$ \\
\hline
\end{tabular}

Forrás: Buzás 2002. 
Hazánkban a kutatás-fejlesztési és innovációs szolgáltatásokat nyújtó intézményrendszerbe az akadémiai intézetek, a felsőoktatási intézmények (elsősorban müszaki egyetemek és föiskolák), valamint a vállalati szféra kutatóhelyei, az alapítványi formában müködő kutatóintézetek, az ipari kutatóintézetek, a technológiai transzfert segítő intézményhálózat, illetve a különleges fejlesztési szolgáltatásokat nyújtó vállalkozások, mérnökirodák, az innovációs és technológiai transzfer központok, klaszter szervezetek és az inkubátorházak tartoznak (MISZ 2001). Mindazonáltal a szereplök között sincsen teljes mértékben egyetértés, hogy mely intézmények, illetve ténylegesen milyen funkciók, tevékenységek sorolhatók e körbe. A fogalom széles körü értelmezése esetén tulajdonképpen minden olyan piaci és nem piaci szereplő ideértendő, aki a kis- és középvállalkozások innovációs teljesítményének javítása, fokozása érdekében valamilyen szolgáltatás formájában vagy saját tudását nyújtja, vagy másét próbálja meg átadni, közvetíteni. Így tulajdonképpen szinte valamennyi vállalkozásfejlesztéssel, illetve gazdaságfejlesztéssel foglalkozó intézmény és szervezet idesorolható. Szüken értelmezve már jóval kisebb ez a kör. Kifejezetten csak a valamilyen innováció, technológia, tudás közvetítését, az azzal rendelkező kínálati és az azt igénylö keresleti oldal közötti kapcsolatok megteremtését szolgáltatásaival elösegíteni képes kört foglalja magába.

Jelen tanulmányban a regionális innovációs rendszer kínálati oldalának a Középdunántúli régióban tapasztalható sajátosságait szeretnénk bemutatni. Vagyis arra keressük a választ, hogy az innovációs rendszer kínálati oldali intézményei milyen erőforrásokkal, mozgósítható kapacitásokkal rendelkeznek, illetve milyen, az innovációs rendszer fejlődését gátló hiányosságok tapasztalhatók müködésükben. Hasonló, a regionális innovációs rendszer kínálati, illetve keresleti oldalának feltárását megcélzó kutatások folytak a Közép-magyarországi, a Dél-alföldi és a Déldunántúli régiókban is (Márton 2004).

A regionális innovációs stratégia számára a kínálati oldal felmérése a regionális technológia- és innováció-támogatás intézményrendszerének a feltárását jelenti, módszertanilag különböző részekböl, egymáshoz szorosan kapcsolódó elemekböl áll. Így elöször a Közép-dunántúli régió innovációhoz szorosan kapcsolódó kutatásfejlesztési teljesítményének, kapacitásának szekunder, KSH adatokon alapuló elemzésére, vizsgálatára kerül sor, elhelyezve a régiót a hazai kutatás-fejlesztési térben. Ezt követően a régióban müködö és az innovációban, vállalkozásfejlesztésben, gazdaságfejlesztésben valamilyen szinten érintett intézményi szereplök és szervezetek kerülnek a fókuszpontba. Az innovációhoz kapcsolódó, illetve azzal összefüggésbe hozható tágan értelmezett intézményi hálózat feltárásának alapját összesen több mint 30 személyes interjú adja (a régióban található felsőoktatási intézmények, kutatóintézetek, innovációs központok és inkubátorházak, klaszter szervezetek, vállalkozásfejlesztési alapítványok, kockázati tőketársaságok, kamarák, MTESZ). A régióban található ipari parkoknak az elemzése, innovációban betöltött és lehetséges szerepüknek, az általuk nyújtott szolgáltatásoknak, együttmúködési kapcsolatrendszerüknek, innovációhoz való viszonyulásuknak bemutatása az ipari parkok 
Grosz András - Csizmadia Zoltán - Szépvölgyi Ákos: A regionális innovációs rendszer kínálati oldala a Közép-Dunántúlon. Tér és Társadalom, 18. 2004. 3. 111-125.

viszonylag nagy száma (összesen 26 szervezet) miatt a személyes interjúk helyett egy speciális, csak a részükre kiküldött kérdőíves felmérésen alapul.

\section{A Közép-Dunántúl fejlödése az innováció szempontjából}

A Közép-dunántúli régió fejlödése a kilencvenes évek elejétől több markáns, az innováció szempontjából lényeges tényezővel jellemezhető. A régióra a kilencvenes évek elején a területi jellemzők alapján még az agrár-ipari jelleg volt a meghatározó. Az elmúlt évtizedben azonban a régió az ipari szerkezetváltás, valamint a mezőgazdaságban bekövetkezett termelés és foglalkoztatás szüküléssel járó változások eredményeképpen átjutott abba a szakaszba, ahol egyértelmüen az ipari (ezen belül is feldolgozó-ipari) jelleg a meghatározó.

$\mathrm{Az}$ átalakulási folyamat az elmúlt évtizedben módosította a vállalkozások fejlődésének legfontosabb tendenciáit és a vállalkozási környezet jellemzöit. Ebből kiemelhetö, hogy az 1990-es évek elejétől a régióban dinamikusan növekedni kezdett a gazdasági szervezetek száma, alapvetỏen megváltozott a tulajdonosi és gazdálkodási forma szerinti összetételük. Ma az ország vállalkozásainak mintegy tizede müködik a régióban, de a vállalkozói aktivitást jelzö 1000 före jutó vállalkozásszám tekintetében (77) a térség valamivel elmarad az országostól (84). A gazdaság innovációs potenciáljának növeléséhez, ezen belül kiemelten a helyi kis- és közepes vállalkozások fejlödéséhez hozzájáruló közvetlen külföldi tökebefektetéseknek döntő szerepe volt a régió gazdasági struktúrájának átalakításában. Mindazonáltal jellemző, hogy a betelepült nagyvállalatok beágyazottsága nem megfelelö, hazai beszállítói kapcsolataik gyengék. Jelentős eltérések tapasztalhatók tehát a gazdasági teljesítmény, vagy a hatékonyság tekintetében a jellemzően exportorientált, döntöen külföldi tulajdonú nagyvállalati szektor, valamint a belső, illetve lokális piacra termelö, alapvetően hazai tulajdonú, kis- és középvállalati szektor között.

Szintén jellemzö, hogy a régióban - túlnyomórészt a hazai tökebefektetéssel alapított vállalkozások tevékenységi körének módosulása következtében - folyamatosan változik a múködő vállalkozások gazdasági ágak szerinti összetétele, egyre magasabb arányt képviselnek a különbözö szolgáltatásokban múködő vállalkozások. A tercier szektor térnyerése követi a nemzetközi tendenciákat, a termelést kiszolgáló informatikai, tervezési, jogi, pénzügyi, marketing, munkaerö-szervezési tevékenységek iránti igény növekszik, ugyanakkor jellemző az is, hogy ezeket a szolgáltatásokat már nem a vállalkozás belsö szervezeti egységei végzik, hanem erre szakosodott szolgáltató cégek.

A területileg koncentrált külföldi müködőtőke-befektetések miatt a régió ipari központjaiban a korszerü termelésszervezési módszerek és fejlett technológiák betelepítése és fejlesztése következtében az ipari termelékenység nagymértékü minöségi növekedése jellemzỏ. A térségbe áramló mủködö külföldi tőke nagysága és az ipari termelés volumene között pozitív korreláció figyelhetö meg, ez okozta a régión belül az ipari termelési érték és hatékonyság differenciált növekedését. 
A régióba betelepült külföldi vállalkozások alacsony anyagigényủ, fejlett technológiát megkövetelö, viszonylag magas élömunka igényü termelést folytatnak, saját eszközökkel, alkalmazottakkal, vagy bérmunka formájában, mindkét esetben zömében import alapanyagokból exportra. Helyben jellemzően csak termelési modulok és részegységek gyártása történik, önálló termékek elöállítására csak kevés esetben kerül sor, ezért alacsony a termelésbe bevont alvállalkozók és beszállítók száma.

Az innováció tekintetében kiemelt szerepủ gépipar foglalkoztatja a munkavállalók mintegy hatodát (50 ezer fó). A gépiparhoz valamivel több mint 800 középdunántúli vállalkozás kapcsolható, különösen az egyéb általános rendeltetésủ gépgyártás, a müszergyártás, a máshova nem sorolt villamosgép-gyártás, a híradástechnikai termék gyártása és az egyéb speciális rendeltetésủ gépek gyártása területén magas a vállalkozások száma.

Végül a régió fejlődése szempontjából lényeges, hogy két dinamikusan fejlődő ipari innovációs erőcentrum, Budapest és Győr között helyezkedik el. Ezek az erőcentrumok hatásukat elsödlegesen az Ml-es autópálya biztosította közlekedési folyosó mentén fekvő ipari központokra (Tatabánya, Komárom), továbbá Esztergomra, Pápára és Fejér megye M7-es autópálya mentén fekvő keleti területeire fejtik ki. Lényeges, hogy e hatások mind a technológiai transzfer, mind pedig munkaerő-piaci vonatkozásban dominánsabbak, mint ezeknek a városoknak a régión belüli gazdasági központokkal való kapcsolata. Ennek oka föleg a régión belüli észak-déli irányú feltáró és tranzit utak hiányában keresendő. A régió más innovációs központjainak (Székesfehérvár, Mór, Veszprém, Dunaújváros) a szomszédos régiók központjaihoz és ipari körzeteihez való kötődése csak nyomokban fedezhető fel, elsősorban beszállítói vonatkozásban az autóipar területén.

\section{A kutatás-fejlesztési tevékenység regionális sajátosságai a Közép-dunántúli régióban}

A vázolt fejlödési folyamat eredményeképpen a Közép-dunántúli régió országos összehasonlításban - a régiót jellemző jelentős területi fejlettségi különbségek ellenére - a legtöbb gazdasági mutató alapján Magyarország legfejlettebb régiói közé tartozik. Gazdasági szerkezete megújult, a térségben letelepedett nemzetközi müködő tőke megteremette a globális folyamatokhoz történő kapcsolódás alapfeltételeit (Baráth-Molnár-Szépvölgyi 2001). A régió kulcs iparágaiban egyre erőteljesebben érzékelhető egyfajta koncentrációs folyamat (klaszteresedés), melynek elősegítése érdekében az elmúlt években klaszter kezdeményezések is alakultak. A korszerü gazdaságfejlesztési és gazdaságszervezési folyamatirányítási rendszerek szélesedő meghonosításának köszönhetően a régió gazdasági teljesítménye nemcsak egyre nő, de szerkezete folyamatosan megújul. A régió - a népesség gyors adaptációs képességének és a tradicionálisan fejlett munkakultúrának köszönhetően - kedvező adottságokkal rendelkezik az innováció befogadására és érvényesítésére. Mindazonáltal az innováción alapuló gazdaságfejlesztést a régióban számos tényező akadályozza mind a regionális innováció keresleti, mind pedig annak kínálati oldala felöl. 
Grosz András - Csizmadia Zoltán - Szépvölgyi Ákos: A regionális innovációs rendszer kínálati oldala a Közép-Dunántúlon. Tér és Társadalom, 18. 2004. 3. 111-125.

A Közép-dunántúli régiónak rendkívül alacsony a részesedése az ország kutatásfejlesztési tevékenységéből összehasonlítva társadalmi-gazdasági súlyával, különösen ha a régiónak az ország gazdaságában betöltött szerepét tekintjuik (exporttevékenységben, külföldi tőke fogadásában stb.). Ugyanakkor e téren az elmúlt öt-hat évben kifejezetten pozitív tendenciáknak, rendkívül dinamikus fejlődésnek lehetünk a tanúi, ha a kutatás-fejlesztés mutatóit kísérjük figyelemmel (2. táblázat).

\section{TÁBLÁZAT}

A K+F néhány mutatójának alakulása 1996-2002 között régiónként és a Közép-Dunántúlon

(The Development of Some Indicators of $R+D$ between 1996 and 2002 by Regions and in Central Transdanubia)

\begin{tabular}{|c|c|c|c|c|c|c|c|c|c|}
\hline \multirow[b]{2}{*}{ Régió } & \multicolumn{3}{|c|}{ Kutatóhely } & \multicolumn{3}{|c|}{ Kutató-fejlesztö } & \multicolumn{3}{|c|}{$\mathrm{K}+\mathrm{F}$ kutatási téma } \\
\hline & 1996 & 2002 & $\begin{array}{l}2002 / \\
1996 \\
\end{array}$ & 1996 & 2002 & $\begin{array}{l}2002 / \\
1996\end{array}$ & 1996 & 2001 & $\begin{array}{l}20011 \\
1996 \\
\end{array}$ \\
\hline $\begin{array}{l}\text { Közép- } \\
\text { Magyarország }\end{array}$ & 710 & 1218 & 1,72 & 12831 & 17711 & 1,38 & 9750 & 12811 & 1,31 \\
\hline Közép-Dunántúl & 64 & 170 & 2,66 & 732 & 1599 & 2,18 & 658 & 1472 & 2,24 \\
\hline Fejér & 20 & 53 & 2,65 & 266 & 791 & 2,97 & 195 & 423 & 2,17 \\
\hline $\begin{array}{l}\text { Komárom- } \\
\text { Esztergom }\end{array}$ & 2 & 25 & 12,50 & 11 & 156 & 14,18 & 9 & 110 & 12,22 \\
\hline Veszprém & 42 & 92 & 2,19 & 455 & 652 & 1,43 & 454 & 939 & 2,07 \\
\hline Nyugat-Dunántúl & 109 & 162 & 1,49 & 830 & 1427 & 1,72 & 796 & 1344 & 1,69 \\
\hline Dél-Dunántúl & 125 & 191 & 1,53 & 1417 & 1827 & 1,29 & 925 & 1424 & 1,54 \\
\hline $\begin{array}{l}\text { Eszak- } \\
\text { Magyarország }\end{array}$ & 101 & 136 & 1,35 & 1160 & 27 & 1,23 & 1010 & 03 & 0,89 \\
\hline Észak-Alföld & 162 & 256 & 1,58 & 2213 & 2724 & 1,23 & 1559 & 1980 & 1,27 \\
\hline Dél-Alföld & 190 & 293 & 1,54 & 2126 & 3049 & 1,43 & 1365 & 1912 & 1,40 \\
\hline Magyarország & 1461 & 2426 & 1,66 & 21306 & 29764 & 1,43 & 16063 & 21846 & 1,36 \\
\hline
\end{tabular}

Forrás: KSH adatok alapján Szépvölgyi és Grosz 2003.

Valamennyi vizsgált tényező esetében a Közép-dunántúli régió tudta a leggyorsabb növekedést felmutatni, mint ahogy a táblázat adataiból is egyértelmủen látszik. Mindazonáltal a gyors fejlődést kiváltó okok között meg kell jegyezni, hogy az 1990-es évek közepén még valamennyi tekintetében a legutolsó helyet foglalta el a régiók közül, így az alacsony bázis könnyen teremtett lehetöséget a magas dinamikára. Fel kell hívni azonban a figyelmet arra a pozitív folyamatra, melynek hatására mára a Közép-dunántúli régió a mutatókat tekintve megelőzte mind az Északmagyarországi, mind pedig a Nyugat-dunántúli régiót, sőt a kutatási témákat vizsgálva még a jelentős egyetemi központtal rendelkezö Dél-Dunántúlt is. A kutatásfejlesztési tevékenység, akár a kutatóhelyek számát, akár a kutatás-fejlesztés területén foglalkoztatottak számát tekintjük alapul, megállapítható, hogy a rendkívül erős budapesti dominanciát követően az országban a nagy egyetemi központok körül koncentrálódik, így a Dél-Alföld és az Észak-Alföld viszonylag jó értékei kifejezetten a szegedi és a debreceni egyetemnek köszönhetöek. 
A kutatás-fejlesztéshez kapcsolódó beruházások nagyságát tekintve a Középdunántúli régió már a harmadik helyet foglalja el az országban, ami alapján megállapítható, hogy a $\mathrm{K}+\mathrm{F}$ beruházások nem elsösorban a nagy egyetemi és kutatóintézeti kapacitásokhoz köthetők, sokkal inkább a külföldi tőkebefektetések határozzák meg területi eloszlásukat. Vagyis a beruházások nagy része vélhetően az ipari kutatási és fejlesztési infrastruktúra fejlesztésére irányul. Ugyanakkor a $\mathrm{K}+\mathrm{F}$ ráfordítások GDP-hez viszonyított arányát tekintve a régió $(0,55 \%)$ rendkívüli mértékben elmarad a hasonló európai uniós értékektől. A kutatás-fejlesztés közép-dunántúli speciális sajảtosságaira a késöbbiekben még visszatérünk.

\section{A Közép-dunántúli régió felsöoktatási rendszere}

A Közép-Dunántúlon a felsőoktatási intézmények súlya lényegesen elmarad az ország többi régiójáétól. Egyedüli jelentős felsőoktatási és kutatási bázisa a Veszprémi Egyetem, amely azonban még ma sem képes regionális campusként funkcionálni. Ehhez párosul egy rendkívül széttagolt felsőoktatási rendszer, amelyben az egyetem mellett található egy állami főiskola, kêt alapítványi formában mủködő főiskola, két régión kívüli egyetemhez kapcsolódó föiskolai képzés, valamint három egyházi felsöoktatási intézmény. A felsöoktatási intézmények egy része mindössze egy évtizedes múlttal, vagy néhány éves önállósággal rendelkezik.

A régió a felsőoktatási hallgatók számát tekintve elmarad a nagy egyetemi központokkal rendelkező térségektől. Felsőoktatási képzési kínálatában meghatározó szerepe van a társadalomtudományi és a müszaki vonalnak, néhány területen azonban továbbra is hiányos, nincsen sem orvosi, sem jogi képzés. Az új intézményeknek és szakoknak köszönhetően jelentős mértékben nőtt az oktatók és a tudományos fokozattal rendelkezők száma, ami nemcsak a felsőoktatás színvonalának növekedése, hanem a mozgósítható kutatási-fejlesztési kapacitások bővülése miatt is fontos tényező, azonban még így is elmarad az országos átlagtól.

A régióban müködő felsőoktatási intézetek kutatóintézeti háttere gyengének mondható, mely alól talán csak a Veszprémi Egyetem tekinthető kivételnek. A régió felsöoktatási rendszerére jellemző, hogy a különböző intézmények közötti együttmüködési kapcsolatok esetlegesek. Egyfelől eltér az állami, illetve az alapítványi formában müködő intézmények müködése, illetve egyes intézmények székhelye a régión kívül található, ami jelentős mértékben csökkentheti az együttmüködési készséget. Másfelöl az oktatás és a kutatás területén lehetséges együttmüködési kapcsolatokat gyengíti a régióra jellemző rossz közlekedési infrastruktúra. Ugyanakkor pozitívumként értékelhető, hogy szúkebb térségưkben a felsőoktatási intézmények gyakran müködnek együtt a vállalkozásfejlesztés területén tevékenykedỏ szereplőkkel (inkubátorházak, innovációs központok, kamarák, vállalkozásfejlesztési alapítványok).

A fenti sajátosságok alapján megállapítható, hogy a régió felsőoktatási intézményei és a helyi gazdaság közötti kapcsolatok - elsösorban képzési profiljuk és együttmúködéseik hiánya miatt - esetlegesek, az intézmények sem az alap, sem az 
alkalmazott kutatások területén nem tudnak megfelelö hátteret biztosítani a régió vállalkozásai számára (Szirmai et al 2002).

\section{Akadémiai és vállalati kutatóintézetek}

A korábban említett $\mathrm{K}+\mathrm{F}$ beruházásokkal ellentétben, amely a külföldi tőke területi eloszlását követi, a kutatóhelyek egyértelmủen a felsőoktatási intézményekben koncentrálódnak, azon belül is elsösorban a Veszprémi Egyetem játszik kiemelkedő szerepet. A Közép-dunántúli régióban az akadémiai tudományos kutatóintézeti hálózatot az Akadémia Veszprémi Teruileti Bizottsága (a tudományos élet első számú területi koordinációs szervezete), valamint mindössze három kutatóintézet képviseli, melyek közül az egyiknek a régión kívül található a székhelye. A három kutatóintézet közül a gazdasági szféra számára közvetlenül hasznosítható, akár piaci termékekben is megnyilvánuló alapkutatásokat egyedül a martonvásári Mezőgazdasági Kutató Intézetben folytatnak, ez az intézet viszonylag széles gazdasági kapcsolatrendszerrel rendelkezik. Az MTA Balatoni Limonológiai Kutatóintézet tevékenysége sokkal szükebb, speciális területet érint, míg az MTA Regionális Kutatások Központja Nyugat-magyarországi Tudományos Intézetének Székesfehérváron müködő kutatócsoportja társadalomtudományi kérdéseket vizsgál.

A régióból egyértelmüen hiányoznak a müszaki, technológiai területen alapkutatásokat végzỏ kutatóintézetek, melyek egy tágabb térség innovációs potenciáljához, az új ismeretek gazdasági szférában való gyors megjelenéséhez nagymértékben képesek lennének hozzájárulni, akcelerálva annak innovációs potenciálját. A régióban található kutatóintézeteknek, valamint a tudományos élet szervezési feladatait ellátó regionális bizottságnak a jövőben mindenképpen nagyobb szerepet kell vállalnia az innovációt támogató szolgáltatások kidolgozásában és megvalósításában, szorosabbra kell füzni a kapcsolataikat a gazdasági szférával, gyakorlati szakembereket kell bevonni a munkába.

A meglehetỏsen hiányos akadémiai kutatóintézeti hálózatot sajnos a vállalati $\mathrm{K}+\mathrm{F}$ sem tudja pótolni, ugyanis az ipari kutatóhelyek száma a Közép-Dunántúlon hasonlóan alacsony. Ezek a kutatóhelyek döntỏen a régióban múködő nagyvállalatokhoz, illetve a tradicionális iparágakhoz kötődnek - mint azt a 3. táblázat is mutatja, pl. vegyipar, acélipar, élelmiszeripar, alumíniumipar -, míg a térség kis- és középvállalati szektorában e területen az elmúlt évtizedben nem nagyon történt elörelépés.

A problémát tovább növeli, hogy a globális és lokális gazdaság és kutatásfejlesztési szervezetek, valamint a nagyvállalatok és a KKV szektor közötti kapcsolat ad hoc jellegú, esetleges és rendkívül hiányos, ami nagymértékben gátolja a termék- és szolgáltatásfejlesztést, valamint a $\mathrm{K}+\mathrm{F}$ kapacitások bövítését. A helyi gazdaság és a $\mathrm{K}+\mathrm{F}$ között gyakorlatilag nincs közvetlen kapcsolat, ezáltal az alkalmazott kutatáson alapuló innovációs láncok kialakulása elenyésző. További gondot okoz a felsőoktatási kutatási kapacitások eröteljes területi koncentrációja mellett a vállalati $\mathrm{K}+\mathrm{F}$ tevékenység hasonló, elsősorban Veszprém-Várpalota-Székesfehérvár-Dunaújváros vonalra jellemző koncentrációja. 
Grosz András - Csizmadia Zoltán - Szépvölgyi Ákos: A regionális innovációs rendszer kínálati oldala a Közép-Dunántúlon.

Tér és Társadalom, 18. 2004. 3. 111-125.

TÉT XVIII. évf. 2004 @ 3

Versenyképesség

119

\section{TÁBLÁZAT}

Jelentös $K+F$ kapacitásokkal rendelkezö vállalkozások a Közép-Dunántúlon*

(Enterprises with Important $R+D$ Capacities in Central Transdanubia)

\begin{tabular}{|c|c|c|c|}
\hline $\begin{array}{l}\text { Sor- } \\
\text { szám }\end{array}$ & Vállalkozás & Település & Megye \\
\hline 1. & Ajkai Alumínium-ipari Kft. & Ajka & Veszprém \\
\hline 2. & Alcoa-Köfém Kft. & Székesfehérvár & Fejér \\
\hline 3. & Bakony Müvek Alkatrészgyártó Rt. & Veszprém & Veszprém \\
\hline 4. & Bakonyi Bauxitbánya Kft. & Tapolca & Veszprém \\
\hline 5. & Bakonyi Erőmü Rt. & Ajka & Veszprém \\
\hline 6. & Biorex Kutató és Fejlesztő Rt. & Veszprém & Veszprém \\
\hline 7. & Cerbona Élelmiszeripari és Kereskedelmi Rt. & Székesfehérvár & Fejér \\
\hline 8. & Dunaferr Acélmúvek Kft. & Dunaújváros & Fejér \\
\hline 9. & Dunaferr Dunai Vasmü Rt. & Dunaújuáros & Fejér \\
\hline 10. & Elekthermax Elektromos Készülékgyártó Rt. & Pápa & Veszprém \\
\hline 11. & Fejértej Parmalat Tejipari Rt. & Székesfehérvár & Fejér \\
\hline 12. & Karsai Rt. & Székesfehérvár & Fejér \\
\hline 13. & Móri Alkatrészgyártó Kft. & Mór & Fejér \\
\hline 14. & Magyar Alumínium Rt. & Várpalota & Veszprém \\
\hline 15. & L\&M Müszaki Vállalkozói Iroda Kft. & Veszprém & Veszprém \\
\hline 16. & Metcons Kutató, Fejlesztỏ és Tanácsadó Kft. & Dunaújváros & Fejér \\
\hline 17. & Nitroil Vegyipari Termelö-Fejlesztő Rt. & Várpalota & Veszprém \\
\hline 18. & Nitrokémia Vegyipari Rt. & Balatonfüzfó & Veszprém \\
\hline 19. & Sonomark Ultrahangtechnikai és Szolgáltató Kft. & Esztergom & $\begin{array}{l}\text { Komárom- } \\
\text { Esztergom }\end{array}$ \\
\hline 20. & Toxikológiai Kutató Központ Kft. & Veszprém & Veszprém \\
\hline 21. & Vekor Korrózióvédelmi, Analítikai Kft. & Veszprém & Veszprém \\
\hline 22. & Victoria Hungarica 21 Szolgáltató Kft. & Pápa & Veszprém \\
\hline 23. & Visteon Hungary Kft. & Székesfehérvár & Fejér \\
\hline 24. & Zenon Kft. & Oroszlány & $\begin{array}{l}\text { Komárom- } \\
\text { Esztergom }\end{array}$ \\
\hline 25. & Zoltek Magyar Viscosa Rt. & Nyergesújfalu & $\begin{array}{l}\text { Komárom- } \\
\text { Esztergom }\end{array}$ \\
\hline
\end{tabular}

* Jelentös $\mathrm{K}+\mathrm{F}$ kapacitással rendelkezönek tekintettük azokat a vállalkozásokat, amelyeknél a kutatásfejlesztés területén foglalkoztatottak létszáma elérte, vagy meghaladta a 10 föt.

Forrás: KSH alapján Szépvölgyi 2003.

\section{A közép-dunántúli ipari parkok innovációt támogató tevékenysége}

A régióban összesen 26 ipari park ${ }^{2}$ müködik egyenletesen lefedve a régió teljes területét. Közép-Dunántúl úttörő szerepet játszott az ipari parkok létrehozásában, aminek köszönhetöen a parkok többsége mára leginkább a növekedési szakasszal jellemezhetô: viszonylag jól kiépített az infrastruktúra, számos nagy létszámú munkàeröt foglalkoztató vállalkozás található a parkokban (Csizmadia-Döry-Rechnitzer 2002; Csizmadia-Grosz 2002).

$\mathrm{Az}$ innováció kiemelkedö jelentőségét minden ipari parkban felismerték, amit bizonyít az is, hogy az innovatív vállalkozások „,becsalogatása” szinte valamennyi park üzletpolitikájában szerepel. Ennek elérése érdekében azonban elsősorban a vállalkozások büdzséjét érintő, a parkok és a települési önkormányzatok által biztosított 
kedvezmények (kedvezményes ingatlanárak, bérleti díjak, helyi iparüzési adómentesség stb.) alkalmazása figyelhetö meg.

$\mathrm{Az}$ ipari parkokat müködtető szervezetek többsége a régióban ugyanakkor úgy foglalt állást, hogy nem látja szükségesnek az olyan szolgáltatási- és intézményi rendszer ,házon belüli” kialakítását, amely segítené, és alapjában véve kiszolgálná a parkon belüli és a térségben müködő vállalkozások innovációs tevékenységét. $\mathrm{Az}$ innovációs szolgáltatások jelenleg vagy teljesen hiányoznak, vagy csak elvétve fordulnak elő. Még a szolgáltatási kör alaptényezöinek tekinthetö információszolgáltatási rendszerek és továbbképzési programok, tanfolyamok megjelenése is minimális. Az elkövetkező néhány évben tervezett bövítési folyamat a legtöbb szolgáltatási formát nem vagy csak nagyon kevés park esetében érinti. A szolgáltatásokhoz hasonlóan az innovációs intézmények jelenléte is minimális a középdunántúli ipari parkok legtöbbjében; ma még nem jelent gyakori, bejáratott tendenciát az ilyen intézmények kialakítása, betelepítése. A legnagyobb valószínüséggel feltehetỏen inkubátorházak és $\mathrm{K}+\mathrm{F}$ orientált vállalkozások fognak megjelenni a közeljövöben.

A belső és a külső innovációs szükségleteket is csak nagyon kevés helyen mérték fel. Az ipari parkok 70-80\%-a nem rendelkezik ilyen vizsgálatokkal, és feltehetően nincs is pontos képük arról, hogy milyen irányúak, összetételüek és volumenüek a területükön, illetve a tágabb térségben müködö vállalkozások innovációs szükségletei. A kontaktus-elemzés segítségével arra a következtetésre juthatunk, hogy a közép-dunántúli térség gazdasági fejlődésében, innovációs potenciáljának a növelésében kisebb-nagyobb szerepet játszó kiszolgáló, szolgáltató, segítő intézmények hálózatába nem integrálódtak be megfelelően az ipari parkok. Nem jelentek még meg azok a szolgáltatások és intézmények, amelyek elösegíthetnék, megkönnyíthetnék, és hatékonyabbá tehetnék a belső cégek és az egyes park hatókörében müködỏ egyéb vállalkozások kutatás-fejlesztési és innovációs törekvéseit.

\section{A vállalkozások számára szolgáltatást nyújtó kínálat oldali szereplök}

A Közép-dunántúli régióban a felsőoktatási- és kutatóintézetek, valamint a külön tárgyalt ipari parkok mellett a regionális innováció kínálati oldalának másik csoportját azok a szervezetek alkotják, amelyek speciális szolgáltatásaik révén részt vesznek az innovatív ötletek megvalósulásában, az új vállalkozások létrehozásában, a vállalkozások versenyképességének javításában. E körbe soroltuk a vizsgálat során az innovációs központokat és vállalati inkubátorházakat, klaszter kezdeményezéseket, a helyi vállalkozásfejlesztési alapítványokat, a kamarákat, a MTESZ szervezeteket, a kockázati tőketársaságokat, illetve magát a regionális fejlesztési ügynökséget.

A legfontosabb csoportját e szervezeteknek talán az inkubátorházak és az innovációs központok alkotják, melyek speciális szolgáltatásaikkal különösen az induló, új vállalkozások számára nyújtanak szolgáltatásokat, de igen széles körü tevékenységük kiterjed a kis- és középvállalkozások teljes körére. Egyértelmü KKV orientációjukkal 
szemben ugyanakkor tevékenységük inkább települési szintünek tekinthető, nem nagyon képesek elérni a távolabb fekvö és müködő vállalkozásokat. Annak ellenére, hogy folyamatos finanszírozási problémáik jelentős mértékben korlátozzák tevékenységüket, a jövőben egyértelmü irányként határozható meg az ingatlanbővítés és fejlesztés, az együttmüködési kapcsolatok kiszélesítése, valamint az innovációhoz közvetlenül kapcsolódó szolgáltatások bövítése, fejlesztése. Az együttmúködési kapcsolatok mélyítésének egyik eredménye a régióban mủködő öt inkubátorház (Székesfehérvár, Veszprém, Dunaújváros, Ajka, Komárom) által létrehozott konzorcium tevékenysége.

A régióban található vállalkozások speciális szolgáltatási igényeinek kielégítése érdekében, illetve a kulcs ágazatokban megfigyelhető klaszterizációs folyamatok erôsítésére több, ún. klaszter szervezet létrehozására került sor az elmúlt években, pl. autóipar, fa- és bútoripar, élelmiszeripar, elektronikai ipar. Ugyanakkor jellemzö, hogy ma még ezek a szervezetek nem képesek betölteni a klaszteresedési folyamatban, elsősorban ágazat-specifikus, célzott szolgáltatásaik révén a nekik szánt szerepet. Egyelöre kezdeti fázisban vannak, a szolgáltatási kör még kialakulófélben, inkább a helyüket kereső szervezetek menedzsmentjének a müködtetése, elfogadtatása és a finanszírozási problémák kezelése van napirenden.

A KKV szektor számára az egyik legszélésebb körủ szolgáltatási palettával a megyei vállalkozásfejlesztési alapítványok rendelkeznek. Tevékenységük a kis- és középvállalkozások finanszírozásától kezdve (mikrohitel), a különböző oktatási, képzési feladatokon keresztül a tanácsadásig szinte mindenre kiterjed. Sokszor a vállalkozások számára közvetlenül nyújtott szolgáltatások mellett fejlesztési tervezéssel járulnak hozzá a megfelelő vállalkozási környezet biztosításához. Az alapítványok kiterjedt egyuittmúködési kapcsolatrendszerrel rendelkeznek. A kamarák is igen sok területen kapcsolódnak a vállalkozásokhoz. Elsödlegesen - közfeladatokat ellátó szervezetként müködve - leginkább az érdekképviselet, az információnyújtás, szolgáltatás, rendezvényszervezés, partnerközvetítés, valamint a képzés és tanácsadás területén nyújtanak szolgáltatásokat.

Általánosan megállapítható, hogy a Közép-dunántúli régióban a regionális innovációs rendszer kínálati oldala túlságosan szétaprózott, a vállalkozások, illetve a vállalkozni szándékozó magánszemélyek számára túlságosan sok szervezet próbál meg valamilyen segítséget, szolgáltatást, képzési programot, tanácsadást nyújtani. A régióban múködő intézmények és szervezetek tevékenységében ráadásul igen jelentős mértékü átfedések tapasztalhatók, a feladatkörök nincsenek pontosan elhatárolva, több szervezet esetében a megszerezhető források függvényében alakul, néha ad hoc jelleggel vállalkoznak különböző feladatok ellátására. Ugyanakkor pedig számos támogatási eszköz, konstrukció, szolgáltatás-típus elérése a régióban müködỏ vállalkozások számára vagy teljes mértékben lehetetlen, vagy csak rendkívül korlátozottan hozzáférhető.

A régióban tỏbb mint 20 olyan szervezet vagy intézmény található, amely valamilyen jellegủ képzést kínál vállalkozásokkal, vállalkozások vezetésével kapcsolatos témakörben. A számos felsőoktatási intézmény mellett vállalkozási képzésben részt 
vesznek többek között a régióban található inkubátorházak, a megyei vállalkozásfejlesztési alapítványok, a kereskedelmi és iparkamarák, az agrárkamarák, illetve a MTESZ helyi szervezetei is. Ugyancsak széles azon szervezetek köre, amelyek üzleti tervezéshez kapcsolódó tanácsadással állnak ügyfeleik rendelkezésére. Legalább 10 szervezet nyújt segítséget különböző gazdasági szolgáltatásokkal (pl. adótanácsadás, jogi tanácsadás, marketing és kommunikációs tanácsadás, számviteli tanácsadás), valamint üzleti kapcsolatépítésben adott segítséggel, távoktatási programokkal. Jóval kisebb azonban azon szervezetek száma, amelyek a vállalkozások által megvalósítani kívánt ötletek finanszírozásában tudnak segítséget nyújtani, míg a kockázati tőke, magvető tőke, illetve a magvető tőke előtti szakaszban lévő vállalkozások számára nyújtott szolgáltatásokból pedig kifejezetten hiány tapasztalható a régióban, nem beszélve az üzleti angyal szolgáltatásról. Hasonlóan, szinte alig akad olyan szervezet, amelyik feladatának tekintené az új, piacképes ötletek felkutatását, felderítését és azt követően annak megvalósításához nyújtandó különböző szolgáltatások nyújtását. A magasabb szintủ szolgáltatások, pl. mentoring, faktoring, szabadalmi jogokkal, szellemi jogokkal kapcsolatos kérdések ugyancsak szinte teljes mértékben hiányoznak a régióból.

A regionális innovációs rendszer egyik gyenge pontja a kínálati oldali szereplők munkájában tapasztalható átfedés, ami a gyenge kommunikáció és a hiányos együttmüködési kapcsolatok miatt viszonylag alacsony hatékonyságú szolgáltatások nyújtását teszi lehetővé. A megfelelő intenzitású együttmüködés az innovatív, vagy legalábbis komoly $\mathrm{K}+\mathrm{F}$ kapacitásokkal rendelkező nagyvállalatok és a kisvállalkozások között éppúgy nem jellemzö, mint a felsőoktatási és kutatóintézetek és a gazdasági szféra, vagy a régióban működő kínálat oldali szereplők között - eltekintve természetesen néhány igen kedvező eredményeket mutató közös kezdeményezéstől. A részben piaci okokra visszavezethető, egymástól elszigetelten történő müködés eredményeként innovációs katalizáló szerepük általában meghatározott partnerekhez kötött, regionális hatásuk kevéssé érzékelhető.

A regionális innovációs rendszer kínálati szereplöinek egyik legfontosabb problémája a folyamatos finanszírozási gondokból adódik, ami nagymértékben csökkenti mindennapi tevékenységük hatékonyságát, szolgáltatásaik minőségét. Nem rendelkeznek egységes finanszírozási háttérrel, a pályázati rendszerek és a központi alapokból megszerezhető források kiszámíthatatlanok, míg a szervezeteket létrehozó tulajdonosi kör - saját pénzügyi problémái miatt - ugyancsak nem képes fenntartani ezen szervezeteket.

Mindazonáltal természetesen vannak a régióban ígéretes - általában szélesebb körü együttmüködésen alapuló - innovációs kezdeményezések is. Így igen szoros kapcsolatot tart fenn egymással a régióban müködő öt inkubátorház, amelyek többször közösen pályáznak, közös projekteket valósítanak meg (pl. közös távoktatási program kidolgozása, internetes megjelenés stb.). Hasonlóan a vállalkozások információval való ellátását szolgálja a több szereplő által kezdeményezett vállalkozói portál, illetve a közép-dunántúli regionális $\mathrm{K}+\mathrm{F}$ portál. A kutatás-fejlesztés és a gazdasági szereplők mind szorosabb kapcsolatának megteremtésére, az eredmények minél gyorsabb 
Grosz András - Csizmadia Zoltán - Szépvölgyi Ákos: A regionális innovációs rendszer kínálati oldala a Közép-Dunántúlon.

Tér és Társadalom, 18. 2004. 3. 111-125.

TÉT XVIII. évf. 2004 - 3

Versenyképesség

123

átültetésére törekszik a Veszprémi Egyetemen az elmúlt években létrehozott Kutatási és Technológiai Központ, valamint a Vegyipari Kooperációs Kutatási Központ.

\section{A Közép-dunántúli regionális innovációs rendszer}

A régióban müködő vállalkozások, különösen a regionális innovációs rendszer kínálati oldalának szereplői által nyújtott szolgáltatásokat igénybevevő kis- és középvállalkozások innovativitását ugyanakkor a néhol hiányos, illetve széttagolt kínálati szolgáltatások mellett számos egyéb, közöttük néhány rendkívül fontos tényezỏ is korlátozza. A KKV szektor akut forráshiányára, finanszírozási problémáira már nem kell felhívni a figyelmet, ugyanakkor a tőkehiány mellett legalább ekkora - ha nem nagyobb - súllyal esik latba a vállalkozásoknál rendelkezésre álló szakértelem (különösen modern menedzsment ismeretek, vállalkozási és szervezési ismeretek, projekttervezés ismeretek) hiánya, amit a legtöbb esetben az innováció jelentőségének fel nem ismerése, a folyamatos megújulás iránti igény hiảnya kísér. Sokkal inkább jellemző az alkalmazotti beállítottság, valamint a rövid távon viszonylag biztosabb szerződéses beszállítói munkák, bérmunkák elótérbe helyezése. A mentalitásbeli, vállalkozói kedvben mérhetỏ különbségek alapján a vállalkozói létre valló kockázatkezelés, sőt inkább kockázatvállalás sajnos még sokáig nem fogja elérni a kívánt szintet a régióban. De az innovációt gátló tényezök között említhetjük meg a modernizációs hiányt, az információhiányt, a bizalmatlanságnak köszönhetỏ együttmủködési kapcsolatok hiányát, valamint a vállalkozásokat körülvevö átláthatatlan bürokráciát.

1997-ben, a Közép-dunántúli régió területfejlesztési koncepciójában jövőképként megfogalmazott „Az innováció régiója” szlogen ${ }^{3}$ - mely azóta a régió valamennyi fejlesztési dokumentumának alapját képezi, ahogy 2001-ben is megfogalmazásra került a Közép-dunántúli régió területfejlesztési programjában ( $A$ Közép-dunántúli régió... 2001) - sajnos üres szlogen maradt. Nem sikerült megvalósítani a régió számára 2000-ben - Magyarországon elsőként - kidolgozásra került regionális innovációs stratégia által megfogalmazott legfontosabb teendöket, mint pl. egy regionális innovációs ügynökség felállitása, regionális innovációs alap létesítése, az innovációt támogató intézményrendszer hatékonyabb mủködésének elérése stb.

Addig, amíg nem tisztul le a területfejlesztési intézményrendszer feladatköre, szervezeti struktúrája, nem számíthatunk arra, hogy a regionális fejlesztési tanácsok hatékonyan tudnák ellátni az innováció elösegítésében, ösztönzésében elvárható feladataikat. Sokkal nagyobb szerep hárul a régióban múködő és a regionális innovációs rendszer kínálati oldalához kapcsolódó különböző szervezetek és intézmények munkájára, s különösen az azok közötti szoros együttmüködésre. A gazdasági háló kialakításában komoly szerepet játszó hídképző szervezetek szorosabb együittmüködése elengedhetetlen, közös szolgáltatói bázis kialakítása és hatékony müködtetése megoldásra váró feladat. Mindenképpen szükségesnek tartjuk e têren a különböző intézmények és szervezetek hatékony müködése érdekében egyfajta regionális koordináció kialakítását. 
Az innováció elösegítésében, ösztönzésében folyamatok vannak és nem áttörések. A kedvező irányú változások érdekében mindenképpen kommunikációs fórumok tömegére lenne szuikség. Ezen kommunikációs folyamatoknak az egyik elindítójaként lehet tekinteni az Innov-Axis regionális innovációs stratégiai programra is, melynek egyik kifejezett célja a különböző szereplök közötti interakciók kezdeményezése, a kommunikáció megindítása, a közös jövöképek kialakítása és megvalósítása érdekében. Érzékeltetni kell a regionális szereplök fontosságát, súlyát. Támogatásban kell részesíteni a régióban elindított innovatív kezdeményezéseket. Szükség van a Közép-dunántúli régióban, a vállal kozásfejlesztés intézményrendszerében ma még párhuzamosan müködő szervezetek tevékenységének koordinálására, illetve fokozatos integrálására.

Az innovációs rendszer kínálati oldalán megjelenö szervezetek müködési sajátosságainak megismerése véleményünk szerint hozzájárulhat ahhoz, hogy a jelenlegi hiányosságokat és problémákat sikeresen tudjuk kezelni. Ezzel elérhető, hogy a meglévő erőforrások mainál hatékonyabb felhasználásával a Régió innovációs képessége javuljon, és gazdasági teljesítménye növekedjen.

\section{Jegyzetek}

${ }^{1}$ A tanulmány alapját a Közép-dunántúli Regionális Fejlesztési Ügynökség Kht. megbízásából az Európai Unió EU5. Keretprogramjában megvalósuló RIS Inno-Axis „Ikerrégiók Magyarországon, Magyarország innovációs tengelye” címủ projekthez az MTA RKK Nyugat-magyarországi Tudományos Intézete által készített háttérkutatás képezi. A projekt témavezetői: Kígyóssy Gábor (KDRFÜ) és Gordos Tamás (Pro-Régió), a kínálat oldali kutatás irányítoja: Grosz András.

${ }^{2}$ A kutatás során fejlettsége, a betelepült vállalkozások és a foglalkoztatottak száma alapján az ipari parkok közé soroltuk az „Ipari Park” címmel nem rendelkező móri iparterületet is.

${ }^{3}$ A területfejlesztési programban megfogalmazott küldetés: „A Közép-dunántúli régió jövöbeli küldetése, hogy az innováció régiójává válva, mintegy magtérségként meghatározó szerepet töltsőn be a hazai modernizációban”. A régió jövőképe: „Az innováció, a megújulás átfogó kiterjesztése, és ennek segítségével a régióban élök életminőségének a folyamatos javítása”, vagy röviden: „A Közép-Dunántúl váljék az innováció régiójává".

\section{Irodalom}

Baráth G.-Molnár B.-Szépvölgyi Á. (2001) Területi egyenlőtlenségek a Közép-Dunántúlon - Tér és Társadalom. 1. 111-129. o.

Buzás N. (2002) Technológiatranszfer-szervezetek és szerepük az innovációs eredmények terjedésében. - Buzás N.-Lengyel I. (szerk.) Ipari parkok fejlödési lehetöségei: regionális gazdaságfejlesztés, innovációs folyamatok és klaszterek. SZTE Gazdaságtudományi Kar-JATEPress, Szeged. 93-108. o.

Csizmadia Z.-Döry T.-Rechnitzer J. (2002) Az ipari parkok innovációs szolgáltatásait segítő intézményés informatikai rendszerek jellemzöi. - Területi Statisztika. 4. 342-358. o.

Csizmadia Z.-Grosz A. (2002) Szervezet-központú hálózatok: az ipari parkok térségi-intézményi kapcsolatrendszerének és együttmúkơdési aktivitásának szerkezeti jellemzői. - Tér és Társadalom. 2. 53-80. o.

Fejér Megyei Statisztikai Tájékoztató. (2002) 1-2. KSH Fejér Megyei Igazgatósága, Székesfehérvár. Goldperger I. (2002) Javaslatok a kis- és középvállalkozâsok kutatás-fejlesztési hátterét erōsitó intézmények, egyïttmüködési hálózatok és támogatási módszerek fejlesztésére. ECOLAB Gazdasági Tanácsadó $\mathrm{Kft}$., Budapest. 
Grosz András - Csizmadia Zoltán - Szépvölgyi Ákos: A regionális innovációs rendszer kínálati oldala a Közép-Dunántúlon.

Tér és Társadalom, 18. 2004. 3. 111-125.

Grosz A. (200I) Az ipari parkokban múködő vállalkozások innovációs tevékenysége. - Mezei C. (szerk.) Évkönyv 2001. PTE Közgazdaságtudományi Kara Regionális Politika és Gazdaságtan Doktori Iskola, Pécs. 213-232. o.

Grosz A. (2002) Közvetítô (hídképző) intézmények innovációs szerepvállalásának erösítése. Kézirat. MTA RKK Nyugat-magyarországi Tudományos Intézet, Györ.

ITC-AMT (2001) Technológia- és tudástranszfer intézményrendszerének fejlesztése különös tekintettel a kis-és középvállalatokra. ITC-AMT Kft., Budapest.

Komárom-Esztergom Megyei Statisztikai Tájékoztató. (2002) 1-2. KSH Komárom-Esztergom Megyei Igazgatósága, Tatabánya.

A Közép-dunántúli régió területfejlesztési programja. (2001) MTA RKK Nyugat-magyarországi Tudományos Intézet-Közép-Dunántúli Regionális Fejlesztési Ügynökség Kht. Györ-Székesfehérvár.

A magyar innovációs rendszer föbb összefüggései. (1999) Országos Müszaki Fejlesztési Bizottság, Budapest.

Márton Gy. (2004) Innovációs potenciál felmérés tanulságai egy elmaradott régióban. - Tér és Társadalom. 3. 127-149. 0 .

MISZ (2001) Az ipari parkok innovációs szolgáltatásait segító intézmény-és informatikai hálózat rend. szerének kidolgozása. Magyar Innovációs Szövetség, Budapest.

MISZ (2002) A magyar kis- és középvállalkozások innovációs képességének fejlesztése. Magyar Innovációs Szövetség, Budapest.

Mosoniné Fried J. (1997) Az innováció névtelen hátországa. A külföldi müködötóke multiplikátor hatása. Országos Mũszaki Fejlesztési Bizottság, Budapest

OMFB (1995) Innovációs folyamatok a magyar gazdaságban. Országos Müszaki Fejlesztési Bizottság, Budapest.

OMFB (1998) Tanulmányok a kis-és középvállalatok fejlesztési stratégiájáról. Országos Müszaki Fejlesztési Bizottság, Budapest.

Szirmai V.-A. Gergely A.-Baráth G.-Molnár B.-Szépvölgyi Á. (2002) Verseny és/vagy együttmüködés (A város és környék kapcsolatai). MTA Szociológiai Kutatóintézet, MTA RKK NYUTI Középdunántúli Kutatócsoport, Budapest-Székesfehérvár.

Veszprém Megyei Statisztikai Tájékoztató. (2002) 1-2. KSH Veszprém Megyei Igazgatósága, Veszprém. 